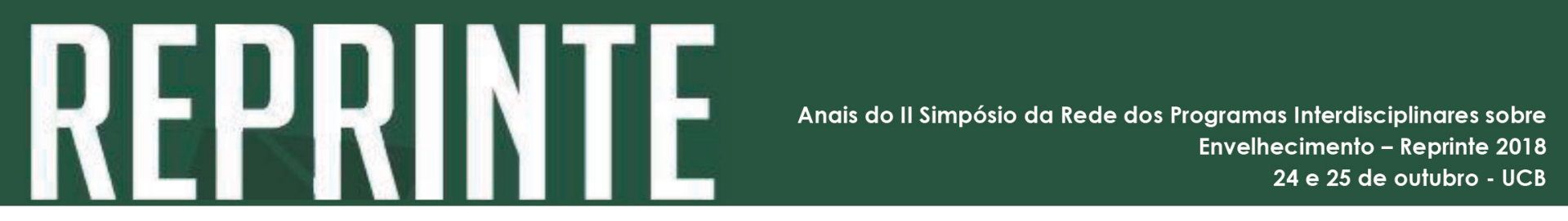

http://dx.doi.org/10.5335/rbceh.v16i1.9757

\title{
11) Análise da Aceitação e do uso das Tecnologias por Idosos: Uma revisão sistemática
}

\author{
Fhernnanda Fernandes Góes'; Lucy de Oliveira Gomes²; \\ Clayton Franco Moraes²; Karla Helena Coelho Vilaça e Silva²
}

\section{Resumo}

O objetivo deste estudo foi analisar, com base na literatura, a aceitação e o uso das tecnologias assistivas pelos idosos. Trata-se de estudo de revisão sistemática em que foi realizada busca por artigos nas bases de dados PubMed/Medline, Lilacs, e Scielo. Os aspectos discutidos na literatura foram: sobre a aceitação, sobre o uso e sobre as variáveis que poderiam interferir nas colocações pré citadas. Considerando estudos nacionais e internacionais, as discussões acerca do tema, de forma geral, foram igualitárias. Fatores como medo, receio, limitações ao acesso das tecnologias e motivação, foram determinantes no resultado do estudo. Notou-se por fim a necessidade de maior informação aos idosos sobre a existência das tecnologias, dos tipos, das categorias e dos benefícios que podem trazer ao idoso, fomentando o interesse no uso, para que a inserção dos idosos seja plena no mundo tecnológico.

Palavras-chave: Tecnologias. Gerontecnologia. Idosos.

\section{Analysis of Acceptance and Use of Technologies by Elders: A Systematic Review}

\section{Abstract}

The objective of this study was to analyze, based on the literature, the acceptance and the use of assistive technologies by the elderly. This is a systematic review in which a search for articles in the PubMed / Medline, Lilacs, and Scielo databases was performed. The aspects discussed in the literature were: on the acceptance, on the use and on the variables that could interfere in the mentioned placements. Considering national and international studies, the discussions on the subject, in general, were egalitarian. Factors such as fear, fear, limitations to technology access and motivation were decisive in the outcome of the study. The need for more information to the elderly about the existence of the technologies, the types, the categories and the benefits that can bring to the elderly, fomenting the interest in the use, so that the insertion of the elderly is full in the technological world.

Keywords: Technologies. Gerontecnology. Seniors.

1 Mestranda no Programa de Pós-Graduação em Gerontologia da Universidade Católica de Brasília. Endereço para correspondência: QS 07 Lote 01 - EPCT - 71966-700 - Águas Claras - Taguatinga - DF. Email: nandagoesfisio@gmail.com

2 Professores do Programa de Pós-Graduação em Gerontologia da Universidade Católica de Brasília. Email: lucygomes2006@hotmail.com; claytonf@ucb.br; kavilaca@yahoo.com.br 